\title{
Granger Causality between Financial Deepening and International Trade: Evidence from Regional Panel Data ${ }^{1}$
}

\author{
Aziz BAKAY *
}

\begin{abstract}
Finance-growth nexus has been a prolific research subject whereas research exploring whether there is an interrelationship between financial system and economic growth is somewhat inconclusive (Levine, 2003). Remarkable studies noted that financial system and its level of development are argued to stimulate economic growth whilst some other important figures in academia investigated the opposite link or simply ignored such association. Current research aims to explore aforementioned association with respect to regional financial deepening in Turkey through developing a panel model and exploring causality. The level of total credits and deposits recorded in each province of Turkey in all banks -regardless of state, private or foreign owned-are utilized as measures of local financial deepening. Foreign trade of each province -both imports and exports- is hypothesized to be determined by financial deepening variables as well as a number of control variables. Results using panel data from 2007-2010 (81 province, N: 324) suggest that credits alone do significantly explain the amount of export and import of that particular province. Interestingly, amount of deposits is negatively associated with the level of imports. Combined measure for provision of financial services (sum of loans and deposits) statistically explains foreign trade (sum of exports and imports). Granger causality analysis revealed that there is bi-directional causal relationship between financial deepening and international trade.
\end{abstract}

Keywords: Foreign trade, financial deepening, regional study, granger causality, Turkey

JEL Code Classification: C58, E44, F40

\footnotetext{
${ }^{1}$ Earlier version of this paper was presented in 2012 Western Hemispheric Trade Conference, Laredo, TX, USA, April 11-12, 2012.

"Assist. Prof. Dr., Gediz University, Department of Logistics Management. Izmir, Turkey, e-mail: aziz.bakay@gediz.edu.tr
}

Copyright @ , 2014 International Ataturk Alatoo University. 


\section{Introduction}

A vast amount of empirical literature has been carried out testing the relationship between finance and economic growth. Financial depth, development of financial sector, banking in general, ownership of banks, and the characteristics of banking sector are among those that have been studied as correlates of economic growth. Studies utilizing cross-country data have linked economic and financial deepening variables; including the legal environment of countries, existence of bankdominated or market-dominated financial systems, inflation, human capital, and urban development along with others.

The mechanism beneath financial system by which the economic development is achieved has not fully revealed in the literature. Wachtel (2003) investigated the investments and growth indicators on a cross-country base. For eighty-seven countries, the correlations between the investment to GDP ratios and subsequent growth rates for 1980 s and 1990 s are 0.43 and 0.24 , respectively. It was found that investment ratios do not differentiate countries with respect to their growth rates. Therefore high rates of investment may not be a remarkable explanatory factor of economic development. In order to effectively channel resources to investments, financial intermediaries should be efficient in carrying out this task (Behname, 2012). The financial deepening and presence of financial intermediaries are of crucial aspects of a well-functioning economy (Akkoç \& Vatansever, 2013), however understanding the underlying black-box between financial system and economic growth and how it relates to each other need further attention. Therefore, exploring the propositions using micro data could illuminate aforementioned gap in this research field.

Financial depth is traditionally hypothesized to be positively associated with the provision of financial services. Increasing financial services allows investors to reach more relevant and improved information about market opportunities, companies, managers and investments alternatives. In addition, financial services include monitoring of investments, and creating intermediation for trading and risk management. Having access to financial services, investors are able to manage risk, investment and portfolios with detailed information and analytical tools. Therefore, measures of financial depth can be utilized as factors explaining economic development that is arguably highly correlated with the foreign trade; imports and exports. Questioning the link between foreign trade of regions and financial deepening in Turkey underlie the primary motivation of the current microeconomic-based study.

\section{Financial Deepening}

In a review of finance-growth literature by Levine (2005), he pointed out that:

The emergence of banks that improve the acquisition of information about firms and managers will undoubtedly alter the allocation of credit. 
Similarly, financial contracts that make investors more confident that firms will pay them back will likely influence how people allocate their savings. (p.869)

In the creation of knowledge with respect to businesses and providing this information to market participants, financial institutions and banks in particular are important actors of today's complex financial system. The functions of the financial system through which economic growth may be stimulated, can be categorized as follows: Generating information about capital allocation and possible investments opportunities, monitoring investments, exerting corporate governance, provide services for and ease trading, diversification and risk management, create savings pool and mobilize them (Levine, 2005).

The investigation for information creation about the types of firms, markets; investors incur a heavy burden of market research costs. Therefore, the investment that requires excessive research and information decreases its chances of flowing to higher value positions. By the presence of financial intermediaries, the information creation about markets, economic conditions, firms and managers; is made easily available to investors allowing better capital allocation (Levine, 2005). Discussion of the financial depth is argued to pose importance in understanding the economic structure and drivers of economy growth.

Earlier studies that have investigated financial deepening brought several indicators into light that could be relevant in capturing the size or the depth of the financial system. These include real rate of interest, savings and investment (Fry, 1978); monetary items such as M3, claims on private sector, importance of the private banks in comparison to Central Bank (King \& Levine, 1993) and others. Influence of financial conditions on savings and growth was demonstrated by Fry (1978). The vitality of financial conditions was empirically supported utilizing national data of seven Asian countries. Ratio of liquid liabilities of the financial system to GDP has been utilized as a measure of financial depth at the country level. In a study by King and Levine (1993), proportion of private sector credits to total credits and to GDP was found to be correlated with economic growth. Besides, the subsequent growth indicators were also predicted by these financial development indicators. The increasing efficiency and capital accumulation by the financial development can be arguably said to lead to economic growth. Beck and Demirgüç-Kunt (2009) discussed a number of indicators measuring the size of the financial system; structure, efficiency and stability of commercial banks offering plenty of analytical tools for delving into the finance-growth subject. Nevertheless, Levine (2003) noted that:

Perhaps the biggest data problem involves the empirical proxies of "financial development," because it is difficult to construct accurate, consistent measures of financial development for a broad cross-section of countries. Thus, more microeconomic-based studies that explore the 
possible channels through which finance influences growth will foster a keener understanding of the finance-growth. (p.31, emphasis added)

Traditional finance-growth or trade-growth literature concedes such a shortcoming of cross-country data and yet one-country studies have to tackle similar problem of measurement. At this junction, current study attempts to explore the association between regional financial deepening and economic activities using constructs that capture the local financial development.

Regional output disparities are often tied into the financial and economic development levels of the regions. Chinese financial system has been studied in the last two decades and it was believed to be the cause of the regional and provincial disparities in output and banking figures (Peng, et al., 2010). The financial system is frequently assumed to siphon off the funds from the poor regions for loans in more prosperous regions, and therefore instigating an uneven regional distribution. This study revealed that there is no empirical reason to propose that financial system in China which consist of mainly state-owned banks transfer deposits from poor regions into loans in wealthy provinces. However, the positive relationship between the financial disparities across regions and output per capita remains significantly important. On the contrary there is literature suggesting that financial services in especially less or intermediately developed regions support the economic development in Philippines (Meslier-Crouzille, et al., 2012). Peng et al. (2010) also conclude with empirical evidence supporting the causality in both short and long runs implying the changes in the disparities of amount of loans would be reflected in the output disparities in provinces. Comparing a drop in the amount of loans by rural credit co-operatives would have an impact on output disparities higher than that of an identical drop in the amount of loans by state-owned banks. Therefore, even though the proportion of state-banks in the economy is remarkable, the policy recommendation in this study focused on the rural (regional) credit co-operatives. As such, the geographical analysis of financial institutions (i.e., credit cooperatives) and regional webs of the financial system at large require attention. In addition, the amount of loans as an empirical measure of financial development proved to explain underlying phenomenon significantly and thus it paves the ground for this study to build the empirical model as discussed in the methodology section.

Rural banking activities and presence of financial intermediaries were addressed with respect to the economic development of the regions within Philippines (Meslier-Crouzille et al., 2012). Research contributed to the literature by showing no evidence towards a banking-led economic development in general, except moderate positive effect of rural banks on the development of less developed regions, and a stronger impact on the intermediately developed regions in Philippines. The national data when disaggregated into provinces or regions can shed light into suggested link between finance and economic growth. It implies a threshold of per capita output that would allow rural banks to stimulate the 
economic growth. Similar econometric research studied a variety of geographic regions including but not limited to Spain (Valverde \& Fernandez, 2004), Cameroon (Johannes, Njong, \& Cletus, 2011), Sub-Saharan African countries (Ahmed, 2010) resulting in mixed conclusions.

There is ample evidence showing the direction as from financial deepening to economic growth. A regional study by Valverde and Fernandez (2004), carrying out the statistical testing of causality can be considered a robust analysis due to having similar macroeconomic, legal, political factors across the places in the same region. Their research examined Spanish banks during a period of 1993-1999 and findings suggested that economic growth can predict the financial deepening. The reason behind was identified as the bank dependence that could change the likelihood of financial exclusion of some households and firms. The aforementioned literature highlighted that the suggested positive link between finance and growth should be investigated cautiously. Nevertheless, the causality and the directionality issues are still vague and needs further exploring. Thus, in order to increase the robustness of the empirical models employed in the statistical analysis, current study attempts to check for granger-causality between finance and international trade figures.

\section{Banking System in Turkey}

Countries that have substantial government role in their financial system may be considered to have relatively limited financial development and productivity. There is particular empirical evidence (La Porta, Lopez-De-Silanes \& Shleifer, 2002) suggesting such proposition. Using a panel of 92 countries La Porta et al. (2002) reported that government ownership is larger in countries with low levels of per capita income, underdeveloped financial systems and lower productivity growth. In this vein, Turkey having one-third of its banks owned by state, can be categorized to have limited financial deepening. However, it can be also argued that state ownership does not always deteriorate the efficiency of the banking activities considering German and French banking system of which is heavily composed of state-banks; $66 \%$ and $75 \%$, respectively.

Onder and Ozyildirim (2010) found that growth rates of per capita GDP in Turkish provinces are influenced by bank credits implying an inconsistent effect. Their research revealed positive association among developed provinces however among less-developed provinces the relationship becomes insignificant or even negative. Similarly, same authors in a follow up research (Onder \& Ozyildirim, 2011) examine the banking industry, and investigate the ownership of banks and how it impacts on the growth in Turkey. This research considers bank credits by government-owned and private banks and results empirically show that only in the well-developed provinces there is support of government-owned banks to the local growth. In addition, the research takes into consideration of the mayors' affiliation in the provinces with the governing party. Using a panel data from 1992-2006, they analyzed the association between bank credits and growth of Turkish provinces and 
whether there is a difference between those mayors that have the political support of the governing party or those of not. Study reveals that credits by governmentowned banks are not significantly predicting the provincial growth. However, in less-developed and provinces with political support, government-owned bank credits are positively and significantly correlated GDP per capita growth rate. Same results are found for the developed and politically non-advocate provinces. On the other hand, the political orientation of majors and the level of development of the cities become irrelevant in explaining the fact that private bank credits stimulate income growth.

\section{International Trade and Economic Growth}

The interaction between international trade and economic growth is based on a number of arguments. The openness of a nation in general in regards to international trade is thus argued to be associated with the economic growth (i.e., Mercan, et al., 2013) due to diffusion of international technological knowledge (Afonso, 2001). Followings are arguments in line with the microeconomic roots rather than country level theoretical explanations. The transferred technology and eventually innovation-led economic activities are stimulated by the importation of capital intensive products (i.e., De Long \& Summers, 1994; Rodrik, 2004). Specifically the imported machinery is the channel of local investment in technology that leverages the accumulation of knowledge. Similarly, Romer (1990) stated that integration with the global economy as well as accumulation of total human capital enhance the economic growth rate. This perspective builds upon the endogenous growth theories that are reflected in the recent literature of reintegration of classical and neo-classical economic theory. In this vein, Afonso (2001) writes:

These growth models allow for an economy to be able to reach a balanced growth path through endogenous forces and underscore the microeconomic foundations of the growth process, identifying in detail the driving force of growth (which is knowledge, generally under the form of technological innovation), its respective dynamics as well as the driving forces which influence its accumulation. Thus, in most new models the determining factor of economic growth is endogenous innovation, and this innovation is still influenced by IT [international trade]. Consequently, the modeling which these new models afford brought with it a more exact approach to the relation between EG [economic growth] and IT. So we can say that the dynamic potential created by IT was decisively recovered more recently with the advent of the models of endogenous growth. (p. 27)

At this junction, current research explores the possible explanation of exports and imports of provinces by loans given and total deposits available by all banks in the respective provinces of Turkey. In addition, model investigates the explanatory 
power of financial depth on the export and imports of provinces as well as total foreign trade rather than employing a growth indicator, tapping on the microeconomic foundations. This research expands the literature by using the financial depth indicator of number of bank branches in provinces. Thus, underlying research develops the field and brings empirical results by attempting to explain foreign trade figures of provinces in a nation-state, Turkey, using financial depth indicators.

\section{Methodology}

\subsection{Empirical Model}

Current study attempts to measure financial deepening through the dollar amounts of total deposits and total loans that are recorded in provinces of Turkey, regardless of bank ownership; state, private or foreign banks. Primary explanatory variables are bank loans and deposits available in provinces of Turkey. The monetary amount of the deposits and loans offered by banks in a province is argued to be reasonable measures to investigate financial deepening (MeslierCrouzille et al., 2012; Onder \& Ozyildirim, 2011). The loan and deposit data was pulled from Turkish Banking Association and international trade figures were obtained from Turkish Statistical Institute (2013) databases. Raw data was classified according to types of deposits and loans. Loans include specialized loans; agriculture, real estate, vocational, maritime, tourism, other and non-specialized loans. The deposits include savings deposits, public sector deposits, commercial deposits, interbank deposits, foreign currency deposits, other institutional deposits, precious metal deposits. The presence of banks in various regions of Turkey is measured by the number of branches of state-owned and private banks which may be also useful proxy of the size of the financial deepening and the financial system across provinces of Turkey. Therefore, in order to obtain robust results, natural logarithms of deposits and loans by provinces are obtained. Natural logs of the foreign trade are used in the analysis. Number of bank branches in provinces is presumably directly linked with the population of provinces therefore; empirical model includes population per branch in provinces as an indicator of financial system. Following is the full description of the analytical model used in the current research:

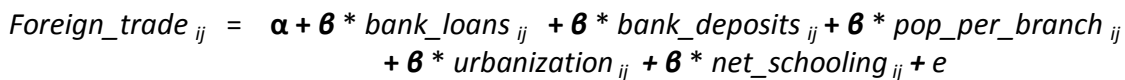

Where;

Foreign_trade ${ }_{i j}$ is the dependent variable that is calculated by taking log of total dollar amount of foreign trade of province $i$ in Turkey in the year $j$. (this variable takes the values of log of total dollar amount of exports, or imports or sum of export and imports).

bank_loans ${ }_{i j}$ is the log of total dollar amount of loans (credits) given by all of the banks in province $i$ in the year $j$.

bank_deposits $i j$ is the log of total dollar amount of deposits available by all of the banks in province $i$ in the year $j$. 
pop_per_branch $i j$ is included in order to capture the population factor in province $i$ in the year $j$.

urbanization $_{i j}$ is the ratio calculated by dividing urban population by total population in the province $i$ in the year $j$.

net schooling ${ }_{i j}$ is the ratio that measures the development level of human capital in province $i$ in the year $j$.

$e$ is the error term.

Net Schooling Ratio was used in the model in order to proxy the human capital that has been studied in prior research as a control variable (King \& Levine, 1993; Onder \& Ozyildirim 2010). Following the definition of Turkish Statistical Institute, data was obtained by dividing the number of students of a theoretical age group enrolled in a specific level of education by the population in that age group. In the sample, net schooling ratio ranges from \%21.43 to \%94.04 in provinces of Ağrı and Bilecik, respectively. Urbanization is another control variable utilized in the prior studies (i.e., Onder \& Ozyildirim, 2011). Because urbanization is an indicator of transformation of the society resulting in industrialization and economic development, the analytical model employs it in order to account for such development of provinces of Turkey. This variable was calculated as dividing the urban population by the total population in provinces.

It is important to note that every province with its unique economic structure and development, require a robust analysis that should tap upon the special aspects of each province. According to Turkish Statistical Institution data, there are five cities whose economic activity is highly important in the sense of their share in the national economy. These cities provide substantial economic growth to the overall national economy. The gross value added figures of these provinces are about $5 \%$ or higher of the national gross value added. These provinces are Istanbul, Ankara, Izmir, Bursa and Kocaeli. Besides, considering the trade volumes, these provinces appear to have the highest trade volumes in the nation in 2010. Their trade shares are; İstanbul (\%52.3), Bursa (\%9.1), İzmir (\%5.9), Kocaeli (\%5.6), Ankara (\%4.7). Similarly, Turkish Economy Ministry (TREM, 2011) published a report of international trade potentials of Turkish provinces. In this report, all the provinces in Turkey were examined on the basis of their export and import potentials. The report projects and highlights the sectors from which the provinces may appropriate competitive advantage in the global market. The growth expectations of provinces and the relevant sectors were identified in the analysis. The report recognizes that some of the provinces have more focus on foreign trade due to higher exports share than their domestic trade share in the nation. Therefore, these provinces happen to be border towns or to be in close proximity to national borders. As such; Ağrı, Antep, Artvin Hakkari, Hatay, Iğdır, Kilis, Mardin, Rize, Şırnak, and Trabzon are the provinces of substantial international trade potential. Considering such information, the unique effects of provinces necessitates that the empirical model should recognize every province as a different and distinct group. 
Thus, fixed effects model creating dummy variables for each of the provinces is employed in the statistical analysis.

\subsection{Statistical Analysis}

Current research employed fixed effects as opposed to random effects regressions. Hausman test determines the best fit of the models in regards to the data. In the case of a fixed effects regression, the analysis takes into consideration of dummy variables for each province resulting in capturing the special conditions only relevant to each province. These factors are assumed to differ across cases (i.e., provinces) but not over time. However, in this research, there are factors assumed to vary across provinces but stay constant over time such as culture, attitude towards banks, banking needs, etc. By the same token, there are factors constant across provinces but might change over time, such as macroeconomic conditions. Aiming to capture the omitted variables with respect to their variation across both provinces and over time, the random effects may appear as a useful panel data analysis for the underlying research question (Princeton University, 2007). Results of fixed effects and random effects models are compared using Hausman test (chisquared=62.81, $p<0.01$ ) and nevertheless fixed effects model fitted to underlying data the best for many of models. Therefore, only fixed effect regression results will be presented in the results section below.

Banking data was pulled from Turkish Banking Association. Exports/imports and data for other variables were obtained from Turkish Statistical Institute from 2007 to 2010 . The sample size was recorded as 324 for four years of data of 81 provinces of Turkey. There is no change in the number of provinces throughout this time period. In Table 1 below; mean, minimum and maximum values of the variables of interest are given. Correlation matrix of variables is given in Table 2. Correlation coefficients of foreign trade, imports and exports with respect to loans, deposits, and sum of loans and deposits are at the 0.70 and 0.80 levels that indicate the strong association between variables of interest.

Table 1. Descriptive Statistics of the Variables for years 2007-2010

\begin{tabular}{lccc}
\hline & MEAN & MIN & MAX \\
\hline Foreign Trade $^{*}$ & $3,560,718$ & 19.69 & $184,814,027$ \\
Export $^{*}$ & $1,409,506$ & 7.92 & $73,503,522$ \\
Imports $^{*}$ & $2,162,236$ & 0.32 & $111,310,504$ \\
Deposits $^{*}$ & $3,833,539$ & 49,495 & $168,662,931$ \\
Loans $^{*}$ & $2,766,103$ & 48,720 & $129,306,354$ \\
Population & 890,085 & 74,412 & $13,255,685$ \\
Population per Branch & 12,452 & 4,313 & 45,056 \\
Urbanization & $\% 62$ & $\% 31$ & $\% 98$ \\
Net Schooling & $\% 63$ & $\% 21$ & $\% 94$ \\
\hline
\end{tabular}

${ }^{*}$ Numbers are in 000s of US dollars. 
Table 2. Correlation Matrix

\begin{tabular}{lccccccccc}
\hline & $\mathbf{1}$ & $\mathbf{2}$ & $\mathbf{3}$ & $\mathbf{4}$ & $\mathbf{5}$ & $\mathbf{6}$ & $\mathbf{7}$ & $\mathbf{8}$ & $\mathbf{9}$ \\
\hline 1 Foreign Trade & 1 & & & & & & & & \\
2 Loans and Deposits & 0.814 & 1 & & & & & & & \\
3 Exports & 0.978 & 0.782 & 1 & & & & & & \\
$\mathbf{4}$ Imports & 0.951 & 0.822 & 0.884 & 1 & & & & & \\
$\mathbf{5}$ Deposits & 0.802 & 0.995 & 0.772 & 0.807 & 1 & & & & \\
$\mathbf{6}$ Loans & 0.820 & 0.993 & 0.788 & 0.831 & 0.977 & 1 & & & \\
7 Population per branch & -0.295 & -0.485 & -0.275 & -0.318 & -0.497 & -0.465 & 1 & & \\
8 Urbanization & 0.581 & 0.590 & 0.542 & 0.610 & 0.579 & 0.594 & -0.329 & 1 & \\
9 Schooling & 0.274 & 0.410 & 0.253 & 0.305 & 0.422 & 0.390 & -0.839 & 0.368 & 1 \\
\hline
\end{tabular}

\section{Results}

For dependent variables of foreign trade, exports and imports, empirical results are shown in Table 3. For each of dependent variable, loans and deposits are posed as the primary explanatory financial deepening variables as well as the population per branch variable. Adjusted R-squared values range from $94 \%$ to $96 \%$. High R-squared values indicate that substantial portion of the variance in the dependent variables is explained.

Table 3. Fixed Effects Panel Data Regression Results

\begin{tabular}{|c|c|c|c|c|c|c|}
\hline & \multicolumn{6}{|c|}{ Dependent variables } \\
\hline & \multicolumn{2}{|c|}{ Foreign trade } & \multicolumn{2}{|c|}{ Exports } & \multicolumn{2}{|c|}{ Imports } \\
\hline Loans + Deposits & $\begin{array}{l}0.58^{* *} \\
(0.257)\end{array}$ & & $\begin{array}{c}0.52^{*} \\
(0.280)\end{array}$ & & $\begin{array}{c}0.54 \\
(0.444)\end{array}$ & \\
\hline Loans & & $\begin{array}{c}1.04 * * * \\
(0.252)\end{array}$ & & $\begin{array}{l}0.71 * * \\
(0.326)\end{array}$ & & $\begin{array}{l}1.85 * * * \\
(0.380)\end{array}$ \\
\hline Deposits & & $\begin{array}{c}-0.47 \\
(0.341)\end{array}$ & & $\begin{array}{c}-0.20 \\
(0.383)\end{array}$ & & $\begin{array}{c}-1.32 * * \\
(0.591)\end{array}$ \\
\hline $\begin{array}{l}\text { Population per } \\
\text { branch }\end{array}$ & $\begin{array}{c}-0.06 \\
(0.059) \\
\end{array}$ & $\begin{array}{c}-0.05 \\
(0.056) \\
\end{array}$ & $\begin{array}{l}-0.11^{*} \\
(0.056) \\
\end{array}$ & $\begin{array}{l}-0.10 * \\
(0.054) \\
\end{array}$ & $\begin{array}{c}-0.02 \\
(0.047) \\
\end{array}$ & $\begin{array}{c}-0.00 \\
(0.043) \\
\end{array}$ \\
\hline Urbanization & $\begin{array}{c}0.31 \\
(0.970)\end{array}$ & $\begin{array}{c}0.05 \\
(0.915) \\
\end{array}$ & $\begin{array}{c}0.36 \\
(1.287) \\
\end{array}$ & $\begin{array}{c}0.21 \\
(1.251)\end{array}$ & $\begin{array}{c}0.01 \\
(0.875) \\
\end{array}$ & $\begin{array}{c}-0.51 \\
(0.812) \\
\end{array}$ \\
\hline Schooling & $\begin{array}{l}-0.01^{*} \\
(0.008)\end{array}$ & $\begin{array}{l}-0.01^{*} \\
(0.009)\end{array}$ & $\begin{array}{c}-0.02 \\
(0.014)\end{array}$ & $\begin{array}{c}-0.02 \\
(0.014)\end{array}$ & $\begin{array}{c}-0.01 \\
(0.011)\end{array}$ & $\begin{array}{c}-0.02 \\
(0.013)\end{array}$ \\
\hline F-statistics & 15.6 & 11.73 & 10.51 & 8.79 & 5.17 & 7.73 \\
\hline$N$ (observation) & 324 & 324 & 324 & 323 & 323 & 323 \\
\hline Adj. R-squared & 0.96 & 0.96 & 0.94 & 0.96 & 0.95 & 0.95 \\
\hline
\end{tabular}

Dependent variables are transformed into the natural logs. Numbers in parenthesis are standard errors.

$* * *, * *, *$ denotes significance at $1 \%, 5 \%$ and $10 \%$ level. Estimates for constant term are not reported.

F-statistics of the models ranging from 5.17 to 15.6 indicate that independent variables jointly and statistically explain the underlying phenomenon. Natural log of the sum of deposits and loans is also used in the models as the combined measure of financial depth of the provinces in dollar amounts. Urbanization level and 
schooling ratio of provinces as socio-economic control variables included in the models as well in order to observe and explore changes in the explained variance of dependent variables.

Sum of deposits and loans as a combined empirical indicator of financial deepening, explained the variance in the respective dependent variables (foreign trade and exports) positively and significantly. The coefficients obtained for sum of deposits and loans for foreign trade is $(\beta=0.58)$ and significant under $\% 5$ level. Sum of deposits and loans explained export levels similarly $(\beta=0.52)$ being significant at $10 \%$ level. Interpretation of these coefficients is as follows: Every $\% 1$ increase in sum of deposits and loans will contribute approximately \%0.6 to the foreign trade of a particular province. Such increase in foreign trade will be realized through the increase in exports rather than due to the improvement in import level.

The individual explanatory power of deposits, and loans varies across the dependent variables. Estimated coefficients of loans are all positive and significant. With respect to foreign trade, estimated coefficient of loans is $(\beta=1.04)$ and significant under $\% 1$ whereas deposits is not statistically significant. With respect to export levels, estimated coefficient of loans is weaker $(\beta=0.71)$ and however significant under $\% 5$ whereas deposits is not significantly associated with exports. With respect to import levels, estimated coefficient of loans is the strongest $(\beta=1.85)$ and significant under $\% 1$. Practically, every $1 \%$ increase in loans in a province, the import levels can be expected to improve almost \%2. On the other hand, interestingly deposits is estimated to deteriorate the imports of a province $(\beta=-1.32$, under $\% 5$ level). Such estimation implies that the simultaneous and equivalent increase in loans and deposits in a province will have opposite impacts on the imports and these influences will partially cancel each other. In such a case, loans will improve imports only marginally.

Population per branch is another proxy that we utilize in order to capture the financial depth in provinces. The results suggest that there is significant association between population per branch and exports. The significant estimations of population per branch for export levels are negative $(\beta=-0.10$ and $\beta=-0.11)$. Negative association implies that less amount of people in a province per bank branch is associated with higher export levels.

Results showed that control variables are practically and statistically not relevant to foreign trade, imports and exports with only one exception: schooling ratio is estimated to be marginally significant and however negative in explaining foreign trade. Therefore, it can be said that urbanization and schooling ratios as indicators of provincial socio-economic development are not relevant measures in regards to export and import levels of a province.

Therefore, current study empirically showed that deposits have no role in stimulating the level of exports and imports in Turkey at provincial level highlighting the substantial role of credits issued by banking sector. 
Considering the association between finance and economic growth in the literature, direction of causality is presented with mixed results including unidirectional causality from finance to growth (i.e., Christopoulos \& Tsionas, 2004), bi-directionality (i.e., Bangake \& Eggoh, 2010; Luintel \& Khan, 1999), and weak evidence for long-run causality (i.e., Neusser \& Kluger, 1998). Some other studies revealed causality effects within the developed countries rather than developing countries (Hurlin \& Venet, 2004; Rousseau \& Vuthioadadorn, 2005) indicating the fact that conditional causality was empirically shown. The causality in this research model is implied to be from financial deepening to international trade. Current study develops and tests a panel granger-causality model in order to address the issue of directionality. The following models involve 1-year lagged variables of international trade figures and financial deepening variables (loans/deposits). The panel data includes yearly provincial data. Arellano-Bond estimations are used and wald test statistics are provided. In Table 4 and 5, granger causality tests' results are presented.

Table 4. Panel Granger Causality Test for Foreign Trade and Export/Import Figures

\begin{tabular}{|c|c|c|c|c|c|c|}
\hline \multicolumn{7}{|c|}{ Dependent variables } \\
\hline & \multicolumn{2}{|c|}{ Foreign trade } & \multicolumn{2}{|c|}{ Export } & \multicolumn{2}{|c|}{ Import } \\
\hline Lagged DV (-1) & $-0.42 *$ & 0.03 & 0.12 & 0.32 & $-1.40 * * *$ & $-0.88 * * *$ \\
\hline Loans + Deposits & $1.54 * * *$ & & $1.52 * * *$ & & 0.91 & \\
\hline Loans & & $1.34 * * *$ & & $1.03 * * *$ & & $1.38 * *$ \\
\hline Deposits & & -0.10 & & 0.28 & & -0.51 \\
\hline $\begin{array}{l}\text { Population per } \\
\text { branch }\end{array}$ & $-0.15 *$ & $-0.15 * *$ & -0.14 & -0.13 & $-0.15 * *$ & $-0.17 * * *$ \\
\hline Urbanization & 4.06 & 2.05 & -3.55 & -6.17 & 10.14 & 6.89 \\
\hline Schooling & $-0.05^{* * *}$ & $-0.04 * * *$ & $-0.04 * * *$ & $-0.03 * *$ & $-0.06 * *$ & $-0.06 * * *$ \\
\hline$N$ (observation) & 162 & 162 & 161 & 161 & 160 & 160 \\
\hline $\begin{array}{l}\text { Wald-Test } \\
\text { (p-value) }\end{array}$ & $\begin{array}{l}59.68 \\
(0.00)\end{array}$ & $\begin{array}{l}62.45 \\
(0.00)\end{array}$ & $\begin{array}{l}25.03 \\
(0.00)\end{array}$ & $\begin{array}{l}25.77 \\
(0.00)\end{array}$ & $\begin{array}{l}89.78 \\
(0.00)\end{array}$ & $\begin{array}{l}94.91 \\
(0.00)\end{array}$ \\
\hline
\end{tabular}

Dependent variables are transformed into the natural logs. Arellano-Bond estimation is employed. $* * *, * *, *$ denotes significance at $1 \%, 5 \%$ and $10 \%$ level. Estimates for constant term are not reported. Robust standard errors are used.

First, model specification is constructed such that financial deepening variables (i.e., loans, deposits and population per branch) are hypothesized to be the cause of exports, imports and total foreign trade. In Table 4, the dependent variables are financial deepening variables and models include lagged dependent variables as explanatory variables. The results are confirming the causal path from financial system to growth in line with particular literature including Levine (2005); Onder and Ozyildirim (2010). Based on the empirical model estimations above, statistical significance of sum of loans and deposits, loans alone and population per branch indicates the strong association between these phenomenon. On the other hand, wald tests are found to be significant $(p<0.01)$ in all models. Thus, sum of loans and 
deposits can be said to granger cause export and total foreign trade. Similarly, loans granger cause exports, imports and total foreign trade. The expansion of financial services and prevalence of the banking system is therefore suggested to be the driver of international trade level of the provinces. In this vein, Bangake and Eggoh (2010) reported that "banking sector is the main channel through which financial development can affect economic growth" (p. 388). Similarly, we found strong evidence that deepening of banking services; especially credits are strongly associated with international trade of the provinces.

Table 5. Panel Granger Causality Test for Loans and Deposits

\begin{tabular}{|c|c|c|c|c|c|c|}
\hline \multicolumn{7}{|c|}{ Dependent variables } \\
\hline & \multicolumn{2}{|c|}{ Loans + deposits } & \multicolumn{2}{|c|}{ Loans } & \multicolumn{2}{|c|}{ Deposits } \\
\hline Lagged DV (-1) & -0.11 & -0.07 & $-1.31 * * *$ & $-1.30 * * *$ & $0.75 * * *$ & $0.83 * * *$ \\
\hline Foreign Trade & $0.08^{* * *}$ & & $0.07^{*}$ & & 0.01 & \\
\hline Export & & $0.03^{* *}$ & & 0.02 & & -0.00 \\
\hline Import & & $0.03 * * *$ & & 0.03 & & 0.01 \\
\hline $\begin{array}{l}\text { Population per } \\
\text { branch }\end{array}$ & -0.00 & -0.01 & $-0.04 * *$ & $-0.04 * *$ & -0.00 & -0.00 \\
\hline Urbanization & 0.64 & 0.76 & 0.65 & 0.42 & $1.11 *$ & $1.29 * *$ \\
\hline Schooling & $0.03 * * *$ & $0.03 * * *$ & $0.07 * * *$ & $0.07 * * *$ & 0.00 & -0.00 \\
\hline$N$ (observation) & 162 & 161 & 162 & 161 & 162 & 161 \\
\hline $\begin{array}{l}\text { Wald-Test } \\
\text { (p-value) }\end{array}$ & $\begin{array}{c}1070.86 \\
(0.00)\end{array}$ & $\begin{array}{c}1117.00 \\
(0.00)\end{array}$ & $\begin{array}{l}318.04 \\
(0.00)\end{array}$ & $\begin{array}{c}315.71 \\
(0.00)\end{array}$ & $\begin{array}{c}1050.66 \\
(0.00)\end{array}$ & $\begin{array}{c}1026.17 \\
(0.00)\end{array}$ \\
\hline
\end{tabular}

Dependent variables are transformed into the natural logs. Arellano-Bond estimation is employed.

$* * *, * *, *$ denotes significance at $1 \%, 5 \%$ and $10 \%$ level. Estimates for constant term are not reported.

Robust standard errors are used.

In table 5, results of the causality tests for loans, deposits and sum of loans and deposits are given. With respect to sum of loans and deposits, international trade variables (exports, imports, and foreign trade) are estimated positively and significantly. Besides, wald tests of all models $(p<0.01)$ show that international trade can cause the financial development. These particular results confirm to the literature that states economic growth is the source of financial deepening (i.e., Valverde \& Fernande, 2004).

In sum, empirical evidence of causality tests indicates that two-way causal paths are true, that is bi-directionality between international trade and financial deepening is a valid argument. The current research results are bringing further evidence to the bi-directional causality literature which is in line with Bangake and Eggoh (2010), Luintel and Khan (1999). Above analysis implies the existence of strong causality between these two economic phenomenon which further raises the questions of whether there is an underlying sequence or other interaction mechanisms. 


\section{Discussion and Conclusion}

Using disaggregated panel data of foreign trade, total deposits and loans by provinces in Turkey, current research investigated the impact of financial depth on the exports and imports of provinces for the time frame of 2007-2010. Turkish Banking Association and Turkish Statistical Institute are the two sources of geographical data of foreign trade, financial depth indicators, urbanization and human capital. Benefiting from the discussions in a report by Economy Ministry of Turkish Republic (TREM, 2011), some particular provinces may have substantial potential of foreign trade rather than domestic trade. Therefore, incorporating fixed effect method in regression models in order to account for group-specific effects, meaningful regression estimates are obtained. The size of the financial system in provinces is proxied by population per branch. Normalized values of the international trade data are included in the statistical models. Among these financial deepening constructs loans appeared to be strongly relevant to international trade figures. Imports and population per branch as size indicators of financial system do not significantly correlate with the international trade figures of provinces. Therefore, the number of bank branches in provinces may not necessarily indicate the depth of financial services and therefore professionals dealing with the expansion process of banks in regards to improving the outreach should employ this variable cautiously.

These results generally concur with the traditional literature (King \& Levine, 1993; Ahmed, 2010; Peng et al., 2010; Onder \& Ozyildirim, 2011) that defines financial depth as a source of growth as opposed to the literature stating that banking-led economic development cannot be clearly shown (Meslier-Crouzille et al., 2012). In this study, results suggested that the financial depth indicators do matter and amount of loans in provinces appear statistically and practically relevant factor that explain the level of exports and imports of provinces that are core components of economic activity. However, the population per branch in provinces did not associate with total foreign trade nor imports. The city development in terms of industrialization measured by urbanization construct appeared insignificant in all models therefore it is not associated with international trade activities. Interestingly, these results disconfirm particular literature stating that in the less/intermediately developed regions there is a stimulating influence of financial system on the economic development (i.e., Meslier-Crouzille et al., 2012; Onder \& Ozyildirim, 2010). On the other hand, the development of human capital measured by schooling ratio is found insignificant in most of the models and practically irrelevant. The granger causality results also suggest that the causality between finance and international trade is bi-directional. Regional economic and financial foundations therefore pose importance in understanding international trade phenomenon and causality among these constructs. Future studies can delve into more integrative causality models considering different perspectives employed 
towards interconnectedness of finance and trade (i.e., Abbas, 2012; Sharma \& Kaur, 2013)

Today, banking sector is shifting from traditional deposit accepting and loan giving nature towards fee-generating service providers (Allen \& Santomero, 2001). For future studies, such change should direct researchers to obtain and craft more accurate indicators and measures for provision of financial services which will enable them to tap on the underlying phenomenon effectively. Even though the recent literature prompts the academia to research on microeconomic foundations financial deepening, the underlying mechanism of how exactly the financial depth influences economic growth and international trade requires theoretical underpinnings which is awaiting ambitious researchers. By bringing empirical evidence, current research contributed to the literature in that size of financial intermediaries and banks measured by the amount of loans and deposits in provinces do matter in the level of foreign trade. Since the international trade and integration of the economy with the global world are factors enhancing the economic growth, regional provision of banking services underlies the transformation of economic activities into trade and eventually leading to economic growth. Therefore, the banks and financial intermediaries are primary elements of the financial development of regions that correlates with the economic activities and international trade of provinces, eventually stimulating growth.

\section{References}

Abbas, S. (2012) "Causality between exports and economic growth: investigating suitable trade policy for Pakistan." Eurasian Journal of Business and Economics 5 (10): 91-98.

Afonso, Ó. (2001). "The impact of international trade on economic growth." Working Paper. Faculdade de Economia, Universidade do Porto.

Ahmed, A. D. (2010) "Financial liberalization, financial development and growth linkages in Sub-Saharan African countries: an empirical investigation." Studies in Economics and Finance 27 (4): 314-339. http://dx.doi.org/10.1108/10867371011085156

Akkoç, S. \& Vatansever, K. (2013) "Fuzzy performance evaluation with AHP and Topsis methods: evidence from Turkish banking sector after global financial crisis." Eurasian Journal of Business and Economics 6 (11): 53-74.

Allen, F. \& Santomero, A. M. (2001) "What do financial intermediaries do?" Journal of Banking \& Finance 25 (2): 271-294.

http://dx.doi.org/10.1016/S0378-4266(99)00129-6

Bangake, C. \& Eggoh, J. C. (2010) "Finance-growth link in OECD countries: evidence from panel causality and cointegration tests." Brussels Economic Review 53 (3/4): 375-392.

Beck, T., Demirgüç-Kunt, A. (2009) "Financial institutions and markets across countries and over time: Data and analysis." (Working paper 4943). Retrieved from World Bank website: http://siteresources.worldbank.org/INTRES/Resources/469232-

$\underline{1107449512766 / \text { Financial Institutions and Markets across Countries.pdf }}$ 
Behname, M. (2012) "The compare of concentration and efficiency in banking industry: evidence from the OPEC countries." Eurasian Journal of Business and Economics 5 (10): 1524.

Christopoulos, D. K. \& Tsionas, E. G. (2004) "Financial development and economic growth: evidence from panel unit root and cointegration tests." Journal of Development Economics 73 (1): 55-74.

http://dx.doi.org/10.1016/j.jdeveco.2003.03.002

De Long, J. B. \& Summers, L. H. (1994) "How robust is the growth-machinery nexus?" In Baldassarri, Paganetto e Phelps, International differences in growth rates: market globalization and economic areas, 5-54.

Fry, M. J. (1978) "Money and capital or financial deepening in economic development?" Journal of Money, Credit and Banking, 10(4), 464-475.

http://dx.doi.org/10.2307/1991576

Johannes, T., A., Njong, A., M., and Cletus, N. (2011) "Financial development and economic growth in Cameroon, 1970-2005" Journal of Economics and International Finance 3 (6): 367375.

Hurlin, C \& Venet, B. (2004) "Financial development and growth: a reexamination using a panel Granger causality test" Document de Recherche LEO, N²004-18, Université d'Orléans.

King, R., G \& Levine, R. (1993) "Finance and growth: Schumpeter might be right." The Quarterly Journal of Economics 108 (3): 717-737.

http://dx.doi.org/10.2307/2118406

La Porta, R., Lopez-De-Silanes, F. \& Shleifer, A. (2002) "Government ownership of banks." The Journal of Finance, 57(1), 265-301.

http://dx.doi.org/10.1111/1540-6261.00422

Levine, R. (2003) "More on finance and growth: more finance, more growth?" Federal Reserve Bank of St. Louis Review 85 (4): 31-46.

Levine, R. (2005) "Finance and growth: theory and evidence." In P. Aghion and S.N. Durlauf (Eds), Handbook of Economic Growth, Volume 1A, (pp. 865-934). North Holland: Elsevier

Luintel, K. B. \& Khan, M. (1999) "A quantitative reassessment of the finance-growth nexus, evidence from a multivariate VAR." Journal of Development Economics 60 (2): 381-405. http://dx.doi.org/10.1016/S0304-3878(99)00045-0

Mercan, M., Gocer, I., Bulut, S. \& Dam, M. (2013) "The effect of openness on economic growth for BRIC-T countries: panel data analysis." Eurasian Journal of Business and Economics: 6 (11): 1-14

Meslier-Crouzille, C., Nys, E., \& Sauviat, A. (2012) "Contribution of rural banks to regional economic development: evidence from the Philippines." Regional Studies 46 (6): 775-791. http://dx.doi.org/10.1080/00343404.2010.529117

Neusser, K. \& Kugler, M. (1998) “Manufacturing growth and financial development: evidence from OECD countries." Review of Economics and Statistics 80 (4): 636-646. http://dx.doi.org/10.1162/003465398557726

Onder, Z. \& Ozyildirim, S. (2010) "Banks, regional development disparity and growth: evidence from Turkey." Cambridge Journal of Economics 34 (6): 975-1000. http://dx.doi.org/10.1093/cje/bep077

Onder, Z. \& Ozyildirim, S. (2011) "Political connection, bank credits and growth: evidence from Turkey." World Economy 34 (6): 1042-1065. 
http://dx.doi.org/10.1111/j.1467-9701.2011.01342.x

Peng, J., He, J., Li, Z., Yi, Y., \& Groenewold, N. (2010) “Regional finance and regional disparities in China." Australian Economic Papers 49 (4): 301-322. http://dx.doi.org/10.1111/j.1467-8454.2010.00404.x

Princeton University (2007) "Data and Statistical Services." Retrieved from: http://dss.princeton.edu/online help/stats packages/stata/panel.htm\#models

Rodrik, D. (1994) "Getting interventions right: how South Korea and Taiwan grew rich." Working Paper, 20th Panel Meeting of Economic Policy, December.

Romer, P. M. (1990) “Endogenous technological change." Journal of Political Economy 98 (5): 71-102.

http://dx.doi.org/10.1086/261725

Rousseau, P. \& Vuthipadadorn, D. (2005) "Finance, investment and growth: time series evidence from 10 Asian economics." Journal of Macroeconomics 27 (1): 87-106. http://dx.doi.org/10.1016/j.jmacro.2003.09.004

Sharma, R. \& Kaur, M. (2013) "Causal links between foreign direct investment and trade: a comparative study of India and China." Eurasian Journal of Business and Economics 6(11): 75-91.

TREM (2011) "Turkish Republic Economy Ministry. Provincial Export Potential Research Report." Retrieved from: http://www.ekonomi.gov.tr/index.cfm?sayfa=index

Turkish Statistical Institute (2013) "Foreign trade statistics." Retrieved from: http://www.turkstat.gov.tr/

Valverde, S., C. \& Fernandez, F. R. (2004) "The finance-growth nexus: a regional perspective." European Urban and Regional Studies 11 (4): 339-354. http://dx.doi.org/10.1177/0969776404046265

Wachtel, P. (2003) "How much do we really know about growth and finance?" Federal Reserve Bank of Atlanta Economic Review 88 (1): 33-47. 